\title{
肥満の生殖内分泌機能に及ぼす影響と 排卯障害の発症に関寸る研究
}

\author{
藤田保健衛生大学医学部産婦人科学教室, *同第二教育病院産婦人科 \\ 樋 口 泰 彦, 奥 村 貴 子, 西 尾 瑞 香, 門 脇 恵, \\ 吉田麻里子, 河上征治, 金 倉 洋一*, 山口陽子*
}

\section{Comparison of Endocrine Features of Obese Menstruating Women and Obese Anovulatory Women}

\author{
Yasuhiko HIGUCHI, Takako OKUMURA, Mizuka NISHIO, \\ Megumi KADOWAKI, Mariko YOSHIDA, Seiji KAWAKAMI, \\ Youichi KANAKURA $^{1 \text { ), and Youko YAMAGUCHI }}{ }^{1)}$ \\ Department of Obstetrics and Gynecology, \\ Fujita Health University School of Medicine, Aichi 470 - 11, Japan \\ *Department of Obstetrics and Gynecology, \\ 2 nd Educational Hospital of Fujita Health University, Nagoya, Japan
}

To examine the relationship between obesity and anovulation, 20 obese and anovulatory women (OA), 14 obese and regularly cycling women (OC), and 12 normal weight and regularly cycling women (NC) were endocrinologically studied. Parameters measured in serum were luteinizing hormone $(\mathrm{LH})$, follicle stimulating hormone (FSH), and prolactin (PRL) levels, and estrone $\left(E_{1}\right)$, estradiol $\left(E_{2}\right)$, estriol $\left(E_{3}\right)$, delta 4-androstenedione (A), free testosterone (free T), and sex hormone binding globulin (SHBG). Blood samples were taken in the early follicular phase in $\mathrm{OC}$ and $\mathrm{NC}$ women.

The body mass indices (BMI) of OA, OC, and NC women were $35.1 \pm 0.9,30.3 \pm 0.5$, and $19.8 \pm 0.4$ (mean $\pm \mathrm{SEM}$ ), respectively. The mean BMI was significantly greater in OA and OC than in NC women (p $<$ $0.00001)$, and even in OA than in OC women $(\mathrm{P}<0.0002)$. Compared to NC women, OA women had increased concentrations of $\mathrm{E}_{1}(84.0 \pm 6.1$ vs $45.8 \pm 3.3 \mathrm{pg} / \mathrm{ml}, \mathrm{P}<0.00001), \mathrm{A}(2.77 \pm 0.25 \mathrm{vs} 1.76 \pm 0.20 \mathrm{ng} / \mathrm{ml}$, $\mathrm{P}<0.02)$, free $\mathrm{T}(2.59 \pm 0.30$ vs $0.83 \pm 0.07 \mathrm{pg} / \mathrm{ml}, \mathrm{P}<0.0002), \mathrm{LH}(8.06 \pm 0.86$ vs $4.99 \pm 1.23 \mathrm{mIU} / \mathrm{ml}$, $\mathrm{P}<0.05)$, LH/FSH ratio (1.45 \pm 0.13 vs $0.78 \pm 0.20, \mathrm{P}<0.05)$, and decreased concentration of SHBG (29.0 $\pm 4.0 \mathrm{vs} 90.9 \pm 9.8 \mathrm{n} . \mathrm{mol} / \mathrm{L}, \mathrm{P}<0.001)$. In contrast, there was no statistical difference in each parameter between OC and NC women, except for decreased SHBG levels $(42.4 \pm 8.2$ vs $90.9 \pm 9.8, \mathrm{P}<0.001)$ in OC women. OA women also had increased levels of $\mathrm{A}(2.77 \pm 0.25$ vs $1.82 \pm 0.21, \mathrm{P}<0.02)$, free $\mathrm{T}(2.59 \pm 0.30$ vs $1.20 \pm 0.28, \mathrm{P}<0.005)$, $\mathrm{LH}(8.06 \pm 0.86$ vs $4.03 \pm 0.71, \mathrm{P}<0.005)$, and $\mathrm{LH} / \mathrm{FSH}$ ratio $(1.45 \pm 0.13$ vs $0.94 \pm 0.17, \mathrm{P}<0.05$ ) compared to $\mathrm{OC}$ women, but there were no differences in FSH, PRL, $\mathrm{E}_{1}, \mathrm{E}_{2}$, and SHBG levels between the two groups. Serum $\mathrm{E}_{3}$ levels were low (below $5 \mathrm{pg} / \mathrm{ml}$ ) in all women examined.

In conclusion, the present study confirmed the previous findings that obese anovulatory women have PCOlike hyperandrogenic menstrual disorders. But, the results also showed that obese regularly cycling 
women did not have this endocine profile, suggesting that obesity itself may not be a primary causative factor of anovulation. Furthermore, the results imply that obesity itself, independent of androgens, may reduce serum SHBG level, and that the decrease in serum SHBG level may not always result in the increase in serum free $T$ levels. However, we could not rule out the possibility that obesity may cause the sequence of endocrine events which result in anovulation as it proceeds, because the mean BMI value of OA women was significantly greater than that of OC women.

Keywords: Obesity, Anovulation, Body Mass Index, free Testosterone, Sex Hormone Binding Globulin

\section{緒言}

1952 年に Rogers と Mitchell ${ }^{1)}$ は無月経を訴える婦人に肥満者が多く存在することを初めて報告し た。それに続く研究に打いて肥満婦人が高率に月経異常や排卯障害を伴らこと2)3) や, 肥満婦人に拉 ける月経異常の多くは肥満の治療, すなわち体重減少により改善されること4)などが明らかにされた ことから，肥満が女性の生殖内分泌機能に対して何らかの影響を及ぼしていることは間違いない。

肥満婦人に护る排卵障害の内分泌的特徵は多囊胞性卵单症候群 (Polycystic Ovary Syndrome; PCOS) に類似した高アンドロゲン性排卵障害とされているが，その発症機序としても過㮃な脂肪細 胞における腺外エストロゲンの産生増加説, 副腎機能の亢進による副腎性アンドロゲン上昇説, 高イ ンスリン血症説, Sex Hormone Binding Globulin (SHBG) の減少による遊離アンドロゲン増加説な ぞの諸説があり，ぞの因子が肥満における排卵障害発症の第一義的要因であるかについてはいまだ一 致した見解が得られていないのが現状である5)6。

加光て肥満婦人の中に正常月経周期を持つ婦人も数多く存在するという事実は, 単純に肥満が「原 因」で排卵障害が「結果」であるという図式が成り立たないことを示唆しており，肥満と排卵障害が 互いに独立して共存する疾患である可能性や, 逆に無排卵の原因となった内分泌異常が肥満の発症に 関与している可能性も否定できない。

そこで本研究では, 肥満と排卵障害の関係をより深く理解することを目的として, 排卵肥満婦人と 無排卵肥満婦人に打ける内分泌学的相違を比較検討し, 肥満が生殖内分泌機能に及ぼす影響について 興味ある成績を得たのでここに報告する。

\section{研究対象と方法}

\section{対 象}

検討対象として当科肥満外来の受診患者のらち，本研究の主旨につき説明を受け同意した肥満婦人 34 名を選んだ。また対照群として正常体重かつ正常月経周期を有するボランティア（Normal weight and regularly Cycling; NC 群) 12 名を選んだ。肥満婦人 34 名はさらに排卵障害を持つ群 (Obese and Anovulatory; OA 群) 20 名と正常月経周期を有する群（Obese and regularly Cycling; OC 群） 14 名に分けた。な拈各群の平均年齢は NC 群 : 24.8 歳, OA 群 : 27.1 歳, OC 群 : 31.0 歳 であった。 


\section{検討項目}

各人の体重, Body Mass Index (BMI) を計測し, 以下の採血を行った。排卯周期を有する OC 群 と $\mathrm{NC}$ 群での採血は卵胞期初期に限定して行った。測定項目は Estrone $\left(\mathrm{E}_{1}\right)$, Estradiol $\left(\mathrm{E}_{2}\right)$, Estriol $\left(\mathrm{E}_{3}\right), \Delta^{4}$-Androstenedione (A), free Testosterone (free T), SHBG, Luteinizing Hormone (LH), Follicle Stimulating Hormone (FSH), Prolactin (PRL) であり, $\mathrm{E}_{1}, \mathrm{E}_{3}$ は RIA (DCC 法)， $\mathrm{E}_{2}, \mathrm{~A}$, free T は RIA（固相法）にて測定， LH，FSH は EIA 法 (IMX), PRL はIRMA 法（ダイナボットディア ビーズ 2), SHBG は FIA 法 (fluoroimmunoassay, DELFIA SHBG kit)にて測定した。

\section{統計分析}

結果は mean \pm SEM で表示した。統計分析は Student’s t-test そて行い, $\mathrm{p}<0.05$ をもって有意差 ありと判定した。

結果

\section{1) 各群の体重と BMI}

正常対照婦人 (NC 群, 12 名) の平均体重と平均 BMI 值は $48.4 \pm 1.3 \mathrm{~kg}$ と $19.8 \pm 0.4$ であった。 全肥満婦人 34 名の平均体重と平均 BMI 值は $81.6 \pm 2.1 \mathrm{~kg}$ と $33.1 \pm 0.7$ であったが, 無排卯肥満婦 人 $(\mathrm{OA}$ 群, 20 名) ではそれぞれ $86.6 \pm 2.6 \mathrm{~kg}$ と $35.1 \pm 0.9$, 排卵肥満婦人（OC 群，14 名）では $74.5 \pm 2.1 \mathrm{~kg}$ と $30.3 \pm 0.5$ であった。OA 及び OC 群の BMI 值は NC 群の BMI 值に較べ有意 $(\mathrm{p}<0.00001)$ 飞高く, また肥満群の中でも OA 群の BMI 值は OC 群のそれに較べ有意 $(\mathrm{p}<$ 0.0002) に高值を示した (Table 1)。

2) LH, FSH, LH/FSH, PRL

$\mathrm{NC}$ 群に打いて血中 LH 值, FSH 值, および LH/FSH 比はそれぞれ $4.99 \pm 1.23 \mathrm{mIU} / \mathrm{ml}, 6.49$ $\pm 0.27 \mathrm{mIU} / \mathrm{ml}, \quad 0.78 \pm 0.20$ であったが, OA 群では $8.06 \pm 0.86 \mathrm{mIU} / \mathrm{ml}, 5.79 \pm 0.44 \mathrm{mIU} / \mathrm{ml}$, $1.45 \pm 0.13$ となり LH 值 $(\mathrm{p}<0.05)$ と LH/FSH 比 $(\mathrm{p}<0.01)$ で NC 群と有意の差が見られた。ま た OA 群はそれぞれの值が $4.03 \pm 0.71 \mathrm{mIU} / \mathrm{ml}, 4.93 \pm 0.70 \mathrm{mIU} / \mathrm{ml}, 0.94 \pm 0.17$ であった OC 群と較べても, LH 值 $(\mathrm{p}<0.005)$ と LH/FSH 比 $(\mathrm{p}<0.05)$ で有意に高值であった。しかし OC 群 では LH, FSH, LH/FSH 比のいずれに沶いても NC 群との間に有意差は認められなかった。血中 PRL 值は OA 群で $17.9 \pm 2.0 \mathrm{ng} / \mathrm{ml}, \mathrm{OC}$ 群で $15.9 \pm 2.1 \mathrm{ng} / \mathrm{ml}, \mathrm{NC}$ 群で $15.2 \pm 2.8 \mathrm{ng} / \mathrm{ml}$ とな り 3 群とも当院の正常範囲 $(10.2 \pm 4.7 \mathrm{ng} / \mathrm{ml})$ をやや上回ったが， 3 群間で有意の差は認められなか った (Table 2)。

3) $\mathrm{E}_{1}, \mathrm{E}_{2}, \mathrm{E}_{1} / \mathrm{E}_{2}, \mathrm{E}_{3}$

$\mathrm{NC}$ 群において血中 $\mathrm{E}_{1}$ 值と $\mathrm{E}_{2}$ 値，そして $\mathrm{E}_{1} / \mathrm{E}_{2}$ 比はそれぞれ $45.8 \pm 3.3 \mathrm{pg} / \mathrm{ml}, 46.5 \pm$ $7.9 \mathrm{pg} / \mathrm{ml}, 1.16 \pm 0.13$ であったが, OA 群では $84.0 \pm 6.1 \mathrm{pg} / \mathrm{ml}, 62.0 \pm 6.0 \mathrm{pg} / \mathrm{ml}, 1.70 \pm$ 0.29 となり， $\mathrm{E}_{1}$ 值のみで $\mathrm{NC}$ 群と有意の差 $(\mathrm{p}<0.00001)$ が見られた。OC 群では同様にそれぞれ $61.9 \pm 10.2 \mathrm{pg} / \mathrm{ml}, 70.7 \pm 17.8 \mathrm{pg} / \mathrm{ml}, 1.26 \pm 0.17$ となり, いずれについても $\mathrm{NC}$ 群や OA 群と の間に有意差は認められなかった。なお $\mathrm{E}_{3}$ 值は測定に供したすべての群，すべての検体において測 定限界値の $5.0 \mathrm{pg} / \mathrm{ml}$ 以下であった (Table 3)。

4) $A$, free $T$, SHBG

血中 $\mathrm{A}$ 值は $\mathrm{NC}$ 群で $1.76 \pm 0.20 \mathrm{ng} / \mathrm{ml}, \mathrm{OA}$ 群では $2.77 \pm 0.25 \mathrm{ng} / \mathrm{ml}, \mathrm{OC}$ 群では $1.82 \pm$ 第 72 巻 第 4 号 
Table 1. Clinical features of the subjects.

\begin{tabular}{|c|c|c|c|}
\hline Group & NC & OA & OC \\
\hline $\mathrm{n}$ & 12 & 20 & 14 \\
\hline Age (years) & $24.8 \pm 1.0$ & $27.1 \pm 1.1$ & $31.0 \pm 2.4$ \\
\hline Weight (kg) & $48.4 \pm 1.3$ & $86.6 \pm 2.6$ & $74.5 \pm 2.1$ \\
\hline BMI & $19.8 \pm 0.4$ & $35.1 \pm 0.9 * *$ & $30.3 \pm 0.5 *$ \\
\hline
\end{tabular}

Values are expressed as means \pm SEM. BMI, Body Mass Index; NC, Normal weight and Cycling; OA, Obese and Anovulatory; OC, Obese and Cycling.

${ }^{*} \mathrm{P}<0.00001$ vs $\mathrm{NC}$ group. ${ }^{* *} \mathrm{P}<0.00001$ vs $\mathrm{NC}$ group and $\mathrm{P}<$ 0.0002 vs OC group.

Table 2. Comparison of serum LH, FSH, and PRL concentrations among the three groups.

\begin{tabular}{|c|c|c|c|}
\hline & NC & OA & OC \\
\hline LH $(\mathrm{mIU} / \mathrm{ml})$ & $4.99 \pm 1.23$ & $8.06 \pm 0.86 *$ & $4.03 \pm 0.71$ \\
\hline FSH $(\mathrm{mIU} / \mathrm{ml})$ & $6.49 \pm 0.27$ & $5.79 \pm 0.44$ & $4.93 \pm 0.70$ \\
\hline $\mathrm{LH} / \mathrm{FSH}$ & $0.78 \pm 0.20$ & $1.45 \pm 0.13 * *$ & $0.94 \pm 0.17$ \\
\hline $\mathrm{PRL}(\mathrm{ng} / \mathrm{ml})$ & $15.2 \pm 2.8$ & $17.9 \pm 2.0$ & $15.9 \pm 2.1$ \\
\hline
\end{tabular}

Values are expressed as means \pm SEM. NC, Normal weight and Cycling; OA, Obese and Anovulatory; OC, Obese and Cycling.

${ }^{*} \mathrm{P}<0.05$ vs $\mathrm{NC}$ and $\mathrm{P}<0.005$ vs $\mathrm{OC} .{ }^{* *} \mathrm{P}<0.01$ vs $\mathrm{NC}$ and $\mathrm{P}<0.05$ vs OC.

Table 3. Comparison of serum $E_{1}, E_{2}$, and $E_{3}$ concentrations among the three groups.

\begin{tabular}{|c|c|c|c|}
\hline & NC & OA & OC \\
\hline $\mathrm{E} 1(\mathrm{pg} / \mathrm{ml})$ & $45.8 \pm 3.3$ & $84.0 \pm 6.1 *$ & $61.9 \pm 10.2$ \\
\hline $\mathrm{E} 2(\mathrm{pg} / \mathrm{ml})$ & $46.5 \pm 7.9$ & $62.0 \pm 6.0$ & $70.7 \pm 17.8$ \\
\hline $\mathrm{E} 1 / \mathrm{E} 2$ & $1.16 \pm 0.19$ & $1.70 \pm 0.29$ & $1.26 \pm 0.17$ \\
\hline $\mathrm{E} 3(\mathrm{pg} / \mathrm{ml})$ & $5.0<$ & $5.0<$ & $5.0<$ \\
\hline
\end{tabular}

Values are expressed as means \pm SEM. NC, Normal weight and Cycling; $\mathrm{OA}$, Obese and Anovulatory; OC, Obese and Cycling.

${ }^{*} \mathrm{P}<0.00001$ vs NC. 
Table 4. Comparison of serum A, free $\mathrm{T}$, and SHBG concentrations among the three groups.

\begin{tabular}{|c|c|c|c|}
\hline & NC & OA & OC \\
\hline A. $(\mathrm{ng} / \mathrm{ml})$ & $1.76 \pm 0.20$ & $2.77 \pm 0.25 *$ & $1.82 \pm 0.21$ \\
\hline free T. $(\mathrm{pg} / \mathrm{ml})$ & $0.83 \pm 0.07$ & $2.59 \pm 0.30 * *$ & $1.20 \pm 0.28$ \\
\hline SHBG (n. mol/L) & $90.9 \pm 9.8 * \star$ & $29.0 \pm 4.0$ & $42.4 \pm 8.2$ \\
\hline
\end{tabular}

Values are expressed as means \pm SEM. NC, Normal weight and Cycling; $\mathrm{OA}$, Obese and Anovulatory; OC, Obese and Cycling.

${ }^{*} \mathrm{P}<0.02$ vs $\mathrm{NC}$ and $\mathrm{OC}$. ${ }^{* *} \mathrm{P}<0.0002$ vs $\mathrm{NC}$ and $\mathrm{P}<0.005$ vs $\mathrm{OC}$. $* * * \mathrm{P}<0.001$ vs OA and $\mathrm{OC}$.

$0.21 \mathrm{ng} / \mathrm{ml}$ となり, OA 群で $\mathrm{NC}$ 群と $\mathrm{OC}$ 群に対し有意に高值を示した $(\mathrm{p}<0.02)$ 。

血中 free $\mathrm{T}$ 值は $\mathrm{NC}$ 群で $0.83 \pm 0.07 \mathrm{pg} / \mathrm{ml}, \mathrm{OA}$ 群では $2.59 \pm 0.30 \mathrm{pg} / \mathrm{ml}, \mathrm{OC}$ 群では $1.20 \pm$ $0.28 \mathrm{pg} / \mathrm{ml}$ となり, $\mathrm{OA}$ 群で $\mathrm{NC}$ 群に対し有意に $(\mathrm{p}<0.0002)$ 高く, また $\mathrm{OC}$ 群に対しても有意に $(\mathrm{p}<0.005)$ 高值を示した。

SHBG 值は NC 群で $90.9 \pm 9.8 \mathrm{n} . \mathrm{mol} / \mathrm{L}, \mathrm{OA}$ 群では $29.0 \pm 4.0 \mathrm{n} . \mathrm{mol} / \mathrm{L}, \mathrm{OC}$ 群では $42.4 \pm$ $8.2 \mathrm{n} . \mathrm{mol} / \mathrm{L}$ となり, NC 群に対し OA 群， OC 群で有意 $(\mathrm{p}<0.001)$ 飞低值を示した (Table 4)。

\section{考察}

肥満婦人が高率に排卵障害を合併することは従来より知られているが，同じ肥満婦人でも排卵障害 を発症する婦人と正常月経周期を持つ婦人が存在することは, 肥満それ自体が必ずしも肥満婦人にお ける排卵障害の絶対的原因ではないことを意味している。本研究は肥満そのものが女性の生殖内分泌 機能に及ぼす影響を解明することを目的として, 肥満婦人を排卵群 (OC 群) と無排卵群 (OA 群) の 2 群に分け，その内分泌学的相違を比較検討した。

今回の検討により, OA 群に颃いては正常婦人 (NC 群) と比較して $\mathrm{E}_{1}$ 值, A 值, free T 值, LH 值, LH/FSH 比が高くSHBG 值が低いことが明らかにされ, 排卵障害を持つ肥満婦人が内分泌的に PCOS 飞類似し高エストロゲン, 高アンドロゲン状態7)8) や LH / FSH 比の上昇9)を示すとした従来 の報告を再確認するものとなった。肥満婦人における排卯障害とPCOS の関係についてはいまだに 議論があり, 肥満婦人に拈いて $\mathrm{E}_{1}$ や $\mathrm{E}_{2}$ の上昇は見られないとした報告 ${ }^{10)}$ や $\mathrm{LH} / \mathrm{FSH}$ 比の上昇は

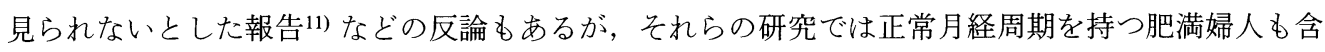
めて検討しており, 肥満婦人を排卵群と無排卵群に分けた今回の検討により少なくとも排卵障害を持 つ肥満婦人においてはその内分泌状態が PCOS 型であることが確認された。また今回の検討で OA 群や $\mathrm{OC}$ 群に执いて $\mathrm{E}_{1} / \mathrm{A}$ 比の上昇や $\mathrm{E}_{3}$ の上昇が認められなかったことは, Loughlin ら ${ }^{12)}$ の末梢 脂肪組織に括ける aromatase 活性六進による排卵障害発症説や Schneider ${ }^{13)}$ らの $\mathrm{E}_{3}$ への変換充進に よる排卵障害発症説を否定する結果となった。

検討対象から OA 群を除き, 排卵を有する婦人の集団（OC 群と NC 群）飞抢いて各因子を比較 
した場合, OC 群と NC 群との間で有意の差が見られた項目はSHBG のみ（OC 群く NC 群）であ り，OA 群と NC 群の間に見られた $\mathrm{E}_{1}, \mathrm{~A}$ ，free T, LH，LH/FSH 比などでは有意の差が認められ なかった。このことから肥満そのものが PCO に類似した高アンドロゲン状態や高 LH 状態を誘起

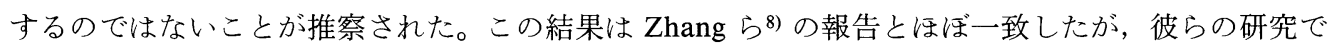
は排卵肥満婦人に抢けるSHBG 值は低下の傾向を示したものの有意ではなかったのに対し，本研究 では SHBG 值は OA 群のみならず OC 群においても NC 群に較べて有意に低值を示すことが証明 され，SHBG は排卵障害の有無に関係なく肥満により減少することが示唆された。また OC 群にお いて SHBG の低下にもかかわらず free T の上昇が認められなかったことは，肥満による SHBGの 減少が二次的な free T の増加をもたらし，その結果排卵障害が発症するといら説1415) を否定するも のとなった。

排卵障害の有無により分類された肥満婦人間に抢ける各因子の比較では, OA 群は OC 群に較べ BMI , LH , LH / FSH 比, A, free T 飞扣いて有意に高值であったが, FSH や PRL, $E_{1}, E_{2}, E_{1} / E_{2}$ 比, SHBG に関しては両群に差を認めなかった。この結果は OA 群における A や free $\mathrm{T}, \mathrm{LH}$ 上昇 が SHBG の低下や $\mathrm{E}_{1}$ の上昇によるものではないことを意味し，これらの上昇に関しては今回検討

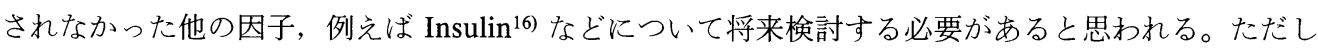
今回の検討において OA 群の BMI が OC 群の BMI に較べ有意に高かったことは, 肥満婦人に拈け る排卯障害が肥満度の増加に比例して発症している可能性も考慮する必要がある。このことはすなわ ち現在正常月経周期を有する肥満婦人でも肥満の進行により将来排卵障害を発症する可能性があるこ とを示唆して打り，同一婦人に打ける肥満の進行と排卯障害の発症について今後検討を加えていく必 要があると考兄られた。また高アンドロゲン血症の有無にかかわらず OA 群と OC 群の間で SHBG 值に有意の差を認めなかったことは, 前述の OA, OC 両群に和ける SHBG 低值と併せて, 肥満者 に拈けるSHBG の減少が高アンドロゲン血症によるもの17)ではなく, 肥満そのものに原因があると

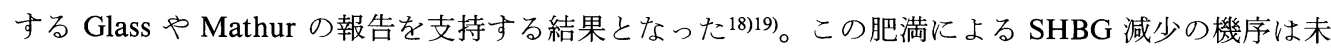
だ解明されていないが，Schneider ら20) は肥満による肝細胞での estrogen receptor の障害が SHBG の合成を抑制しているのだろうと主張しており，また最近では高 Insulin 血症が低 SHBG の原因で あるとする報告もみられる21)。

以上の成績ををとめると，1）無排卵肥満婦人には PCOS 型の内分泌異常が見られるが，排卵肥満 婦人にはその内分泌異常が認められないことが証明され, 肥満そのものは高アンドロゲン, 高 LH 型の生殖内分泌系の異常に直接関与していない可能性が示唆された。2）しかし無排卵肥満婦人と排 卵肥満婦人との間で肥満度に有意の差（無排卵群＞排卵群）が見られたことから，肥満婦人に括ける 内分泌異常, 排卵障害はその肥満度に比例して発症するという可能性も否定はできない。3）血中 SHBG 濃度は血中アンドロゲン濃度とは関係なく肥満そのものにより減少することが示唆され，ま た SHBG の減少は必ずしも血中 free T 濃度の上昇に結びつかないことが証明された。

\section{参 考 文 献}

1) Rogers, J., Mitchell, G.W.: The relation of obesity to menstrual disturbances. N. Engl. J. Med. 1952; 53 - 55

2) Hartz, A.J., Barboriak, P.N., Wong, A., Katayama, K.P., Rimm, A.A.: The association of obesity with infertility and 
related menstrual abnormalities in women. Int. J. Obes. 1979; 3: $57-73$

3) 河上征治, 橋本 透, 安康善雄 : 体重変動之月経異常. 産婦人科 MOOK 29 巻. 1984: 204-210

4) Bates, G.W., Whitworth, N.S.: Effect of body weight reduction on plasma androgens in obese, infertile women. Fertil. Steril. 1982; 38: $406-409$

5) Friedman, C.I., Kim, M.H.: Obesity and its effect on reproductive function. Clin. Obstet. Gynecol. 1985; $28: 645-663$

6) Azziz, R.: Reproductive endocrinologic alterations in female asymptomatic obesity. Fertil. Steril. 1989; 52: $703-725$

7) Bates, G.W., Whitworth, N.S.: Effects of obesity on sex steroid metabolism. J. Chronic. Dis. 1982; 35: $893-896$

8) Zhang, Y.W., Stern, B., Rebar, R.W.: Endocrine comparison of obese menstruating and amenorrheic women. J. Clin. Endocrinol. Metab. 1984; 58: $1077-1083$

9) Kaufman, E.D., Mosman, J., Sutton, M., Harris, M.B., Carmichael, C.W., Yen, S.S.: Characterization of basal estrogen and androgen levels and gonadotropin release patterns in the obese adolescent female. J. Pediatr. 1981; 98: 990 - 993

10) Zumoff, B.: Relationship of obesity to blood estrogens. Cancer Res. 1982; 42 (8 Suppl): $3289 \mathrm{~s}-3294 \mathrm{~s}$

11) Kopelman, P.G., White, N., Pilkington, T.R., Jeffcoate, S.L.: The effect of weight loss on sex steroid secretion and binding in massively obese women. Clin. Endocrinol. Oxf. 1981; 15: $113-116$

12) Loughlin, T., Cunningham, S.K., Culliton, M., Smyth, P.P., Meagher, D.J., McKenna, T.J.: Altered androstenedione and estrone dynamics associated with abnormal hormonal profiles in amenorrheic subjects with weight loss or obesity. Fertil. Steril. 1985; 43: $720-725$

13) Schneider, J., Bradlow, H.L., Strain, G, Levin, J., Anderson, K., Fishman, J.: Effects of obesity on estradiol metabolism: decreased formation of nonuterotropic metabolites. J. Clin. Endocrinol. Metab. 1983; 56: $973-978$

14) Hosseinian, A.H., Kim, M.H., Rosenfield, R.L.: Obesity and oligomenorrhea are associated with hyperandrogenism independent of hirsutism. J. Clin. Endocrinol. Metab. 1976; 42: $765-769$

15) Plymate, S.R., Fariss, B.L., Bassett, M.L., Matej, L.: Obesity and its role in polycystic ovary syndrome. J. Clin. Endocrinol. Metab. 1981; 52: $1246-1248$

16) Barbieri, R.L., Smith, S., Ryan, K.J.: The role of hyperinsulinemia in the pathogenesis of ovarian hyperandrogenism. Fertil. Steril. 1988; 50: $197-212$

17) Anderson, D.C.: Sex-hormone-binding globulin. Clin. Endocrinol. Oxf. 1974; 3: 69-96

18) Glass, A.R., Swerdloff, R.S., Bray, G.A., Dahms, W.T., Atkinson, R.L.: Low serum testosterone and sex-hormonebinding-globulin in massively obese men. J. Clin. Endocrinol. Metab. 1977; 45: $1211-1219$

19) Mathur, R.S., Moody, L.O., Landgrebe, S.C., Peress, M.R., Rust, P.F., Williamson, H.O.: Sex-hormone-binding globulin in clinically hyperandrogenic women: association of plasma concentrations with body weight. Fertil. Steril. 1982; 38: $207-211$

20) Schneider, G., Kirschner, M.A., Berkowitz, R., Ertel, N.H.: Increased estrogen production in obese men. J. Clin. Endocrinol. Metab. 1979; 48: $633-638$

21) Peiris, A.N., Sothmann, M.S., Aiman, E.J., Kissebah, A.H.: The relationship of insulin to sex hormone-binding globulin: role of adiposity. Fertil. Steril. 1989; 52: $69-72$

（受付日：'95, 8, 8)

(採択日：'95, 11, 6) 